\title{
A day late and a dollar short
}

\author{
Saqib Masroor ${ }^{1}$ \\ ${ }^{1}$ University of Toledo Medical Center
}

October 14, 2020

\begin{abstract}
This is an invited commentary on robotic reoperative surgery without cardioplegia. Tips and shortfalls are discussed.
\end{abstract}

\section{Hosted file}

Day late and a dollar short.pdf available at https://authorea.com/users/316008/articles/ 486725-a-day-late-and-a-dollar-short 